\title{
Accelerating the Future into the Present: Re-imagining Higher Education in the Caribbean
}

\author{
Hilary Beckles and Stacy Richards-Kennedy
}

Progressive societies invest in higher education institutions to help them meet their current and anticipated workforce needs, to find innovative solutions to their most pressing development problems, to think deeply and push the frontiers of knowledge and to help craft a better future. The response of universities globally to the current COVID-19 pandemic, by mobilizing scientific, psycho-social, macro-economic and virtual pedagogical expertise, has demonstrated how critical universities are to securing the present and future needs of society. This foundational mission of higher education has, undoubtedly, been the driving force of societal development. History has shown that universities are the lifeblood of societies, strengthening individual capacity to think critically and creatively and honing collective technical and social skills for global advancement. Today, however, as the world continues to fight a deadly virus that has brought some economies to a standstill, there are fundamental questions that the leadership of all universities, public and private, big and small, must confront: how do universities foresee higher education meeting the future needs of individuals and society? Will universities be agile enough to undertake the rapid organizational transformation necessary for their continued relevance and survival? Will there be a sustained commitment by governments to invest in the higher education sector as the bedrock of human enlightenment, justice, peace and progress?

H. Beckles $(\varangle) \cdot$ S. Richards-Kennedy

The University of the West Indies, Kingston, Jamaica

e-mail:vcoffice@uwimona.edu.jm

S. Richards-Kennedy

e-mail: stacy.kennedy@sta.uwi.edu

(C) The Author(s) 2021 


\section{Higher Education and the Caribbean in Context}

A first step to unpacking the discourse around the future of the university is understanding and reflecting on the context in which Caribbean universities operate. The Caribbean education system itself is a product of the region's history which has been shaped by exploitation, slavery and colonialism for centuries. Thus, the residual structural inequity in Caribbean society also manifests itself in the education system. With the lowest higher education enrolment in the hemisphere, the Caribbean's tertiary enrolment rate is less than $25 \%$ compared with the North American average of near $60 \%$ and the Latin America average of 52\% (The World Bank 2020). Disparities within the Caribbean sub-region are also quite concerning. Enrolment rates in Eastern Caribbean countries lag behind the rest of the Caribbean with only $15 \%$ of secondary school graduates going on to pursue tertiary education and less than $10 \%$ of adults having successfully undertaken programmes at the tertiary level (OECS Secretariat 2012). Gender disparities and a lack of opportunity for the most vulnerable add further complexities (OECS Secretariat 2012). This, in turn, hinders the potential of many workers who do not have the necessary skills, competencies and knowledge to function effectively and contribute to building the competitiveness of the sub-region.

The vestiges of slavery and indentureship are also visible in the health challenges that afflict Caribbean people. Chronic non-communicable diseases such as diabetes and hypertension disproportionately affect Caribbean people, and this is, in large part, owing to centuries of poor diet heavily concentrated in food with high sugar, oil and salt content. In 2016, more than $76 \%$ of total deaths in the non-Latin Caribbean (excluding Haiti) were due to non-communicable diseases, $58.8 \%$ of which were caused by cardiovascular diseases, cancer (17.2\%) and diabetes (10.8\%) (Caribbean Public Health Agency 2020).

The IPCC Special Report, Global Warming of $1.5^{\circ} \mathrm{C}$, highlighted the extent to which the Small Island Developing States (SIDS) of the Caribbean are disproportionately affected by climate change and suffer frequent and extreme weather events. Between 2017 and 2019, three mega-hurricanes, Irma, Maria and Dorian had a devastating impact on countries in the region. Damage caused by the 2017 hurricanes, Irma and Maria, was estimated at almost US $\$ 100$ billion (Ram 2019), with the Gross Domestic Product (GDP) of countries being decimated in several cases. Estimates of damage caused by these hurricanes was $225 \%$ of GDP in Dominica; more than $300 \%$ of GDP in British Virgin Islands; $10 \%$ of GDP in Antigua and Barbuda, with 95\% of buildings destroyed in Barbuda; and near 100\% of GDP in Anguilla (Smith 2018). Estimates of the total cost of the impacts and effects of Hurricane Dorian, which hit The Bahamas in 2019 was US\$3.4 billion, $25 \%$ of the country's GDP (Inter-American Development Bank 2019). Despite these acute vulnerabilities, the Caribbean region continues to have limited access to concessionary financing, and multilateral development banks continue to maintain GDP as the primary means of eligibility for official development assistance. 
The current COVID-19 pandemic has joined chronic diseases and climate change as the third deadly ' $\mathrm{C}$ ' to afflict the Caribbean. Keeping in mind the scientific evidence that global warming, changing weather patterns and human activity contribute to the spread of infectious diseases, the current pandemic exemplifies the crippling effect that infectious diseases can have on our highly interconnected, globalized world economy and the duty of universities to provide the scientific evidence needed for collective and coordinated action. Since March 2020, Caribbean universities have mobilized all resources at their disposal in an attempt to support governments' efforts at containing the spread of the virus and contributing to re-building more resilient societies. The University of the West Indies (The UWI), like over 50 sister higher education member institutions of the regional network, Universities Caribbean, worked closely with the public and private sector to facilitate a robust COVID-19 response.

As at end-May 2019, the English-speaking Caribbean has been recognized as having the lowest rates of COVID-19 related deaths in North America, Europe and Latin America. This is in part due to the work of The UWI's COVID-19 Task Force, formed prior to the first COVID-19 case entering the region. The UWI's Task Force provided data, public health modelling scenarios and policy guidance to regional decision-makers. Caribbean populations were also kept informed via our UWI-TV Global public education channel. The biggest lesson here for universities in the future is that, owing to the limited capacity of the Caribbean's healthcare system, Caribbean leaders recognized the importance of acting on the guidance of university scientists and other global experts and took swift action to protect lives, thereby demonstrating that where political will and science converge, the outcome will be in the best interest of the society.

The regional approach adopted by the Caribbean is rooted in the Caribbean's strategy to overcome challenges of size, geographical dispersion, and limited resources through regionalism. Organizations such as the Caribbean Community (CARICOM), Organization of Eastern Caribbean States (OECS), Caribbean Development Bank (CDB), Caribbean Regional Public Health Agency (CARPHA) and The UWI have been hallmarks of Caribbean society, built on a common history and motivated by a shared vision of a prosperous and sustainable future. The largest and most longstanding public higher education institution in the Caribbean, The UWI was founded in 1948 to serve Caribbean development, and it has evolved from a college at Mona, Jamaica with 33 medical students into a regional university with near 50,000 students across 5 Campuses serving 17 Caribbean nations and with eight global centres established in partnership with world-class universities across five continents. In many ways, the Caribbean's regional university has served to unlock the potential of Caribbean people and has contributed to shaping the identity, social fabric, and leadership of the region through education. 


\section{Re-imagining the Caribbean University}

Without a doubt, the current pandemic has accelerated the future of higher education into the present. Now forced to grapple with a volatile, uncertain, complex and ambiguous (VUCA) environment that warrants restructured workplaces, redefined roles and rapid learning, universities have had to quickly pivot and reposition themselves for enhanced relevance and competitiveness. In looking towards the future, universities are tasked with undertaking visioning exercises to deliver on the promise of higher education within an ongoing pandemic and post-pandemic paradigm and within a tighter fiscal space. Attempting to future-proof the university's academic and business operations, once a noteworthy goal of strategic planning, now seems like a futile exercise in an environment where the contraction of time is so rapid, the financial impact is so acute, and the urgency to respond to current stakeholder needs is so intense. This has implications for teaching modalities, enrolment rates, graduation rates, internationalization, mobility, student residential life, university academic, sporting and cultural events, institutional financing and so much more.

University leadership teams, therefore, face the difficult task of ensuring the survival of the university as an institution, in many instances rapidly adjusting its business model, cutting and re-training staff and rationalizing its teaching and research agenda, while at the same time preserving and enacting the university's societal mission as the engine of teaching, research, innovation and entrepreneurship for the societies it serves. In the Caribbean, a region whose commodity and tourism-dependent economies will suffer significant shocks as a result of the economic impact of the pandemic, the prospect for receiving traditional levels of government subvention in support of higher education institutions is quite bleak.

Against this regional landscape characterized by unprecedented macro-economic challenges, the search for more sustainable financial models for Caribbean universities must be deliberate and aggressive. The UWI, like many public universities in the region, is currently engaged in this process. With a laser-sharp focus on expenditure reduction and revenue generation, new financial strategies including innovative debt and equity instruments, debt for asset swaps as well as regional and international collaborations to underwrite entrepreneurial ventures, are being explored to supplement traditional financial contributions by governments and tuition fees from students. Diversification of product, price, pedagogy and partnerships will need to be pursued while maintaining our regional university's commitment to quality, its international ranking among the top $4 \%$ of universities globally and its brand promise as a university committed to integrity, excellence, gender justice, diversity and studentcentredness.

At the faculty level, greater attention will need to be placed on flexible teaching and learning modalities to provide online experiences that retain some of the richness of in-person interactions while benefiting from the advantages of distance education such as increased access, self-paced learning, quick re-skilling and re-tooling of adult learners as well as greater diversity and portability of certification through micro and digital credentialing. The immediate future will see Caribbean univer- 
sities upgrading their offering with new digital technologies, robust and integrated business enterprise systems, expanded online and blended teaching, complemented by targeted experiential learning. Universities will also invest in new pedagogical material and approaches that allow for smooth transitions to virtual delivery and online business continuity when necessary. These are all part of the Caribbean's journey towards increased resilience, as was envisioned by CARICOM's Pathway for Resilient Development. This new university model will thus take into account the new possibilities generated by artificial intelligence, blockchain technology and other evolutions of digital technologies, the rapidly changing world of work which requires more knowledge-intense skills than before and also the need to bridge the digital divide so that we leave no one behind.

As the future of global universities unfolds, Caribbean universities that were established primarily as developmental universities to contribute to strengthening democracy in the post-independent period shall remain true to their mission, carrying forward the ethos of Caribbean society. No doubt this will entail reinventing the academe as a more agile and effective institution to better serve the evolving needs of the workforce and wider society. It will also involve harnessing the university's collective disruptive thinking to produce a shift in regional and global development paradigms for a more just and sustainable future for all. Going beyond the concept of higher education in service of the higher purpose of education, Caribbean universities must continue to nurture the human and social capital upon which the future of Caribbean society rests.

During this UN-declared Decade of Action, we are summoned to unite behind science and work in concert towards shared global goals. The experience of the pandemic underscores the extent to which countries and regions are interconnected. The pathway to more sustainable futures will, therefore, require a fervent commitment to science diplomacy, multilateralism, and partnerships. Regional and international networks will be harnessed by universities now more than ever before, to build trust, advance knowledge exchange and foster deeper collaborations for greater societal impact. The celebration of the International Association of Universities' 70th anniversary through this publication could not be timelier. The IAU continues to be a beacon of reflection and action on common priorities that promote respect for diversity and social responsibility — an endeavour for which higher education institutions must increasingly use their voice as they work together to build new, more inclusive frameworks for cooperation and development.

\section{References}

Caribbean Public Health Agency. (2020). What we do: Overview. Retrieved from: https://carpha. org/What-We-Do/NCD/Overview (01.06.2020).

Inter-American Development Bank. (2019). Damages and other impacts on Bahamas by Hurricane Dorian estimated at \$3.4 billion: report. Retrieved from: https://www.iadb.org/en/damages-andother-impacts-bahamas-hurricane-dorian-estimated-34-billion-report (01.06.2020). 
Jamaica Information Service. (2020). Caribbean Focused on Building Resilience in Tourism. Retrieved from: https://jis.gov.jm/caribbean-focused-on-building-resilience-in-tourismminister-bartlett/ (25.05.2020).

McCowan, Tristan. (2019). Higher education for and beyond the Sustainable Development Goals. London: Palgrave Macmillan.

OECS Secretariat. (2012). OECS Education Sector Strategy 2012-2021. Retrieved from: https://www.oecs.org/en/our-work/r/research-and-publication/oecs-education-strategy/ viewdocument/520 (25.05.2020).

Ram, J. (2019). 2019 Annual News Conference. Speech. Caribbean Development Bank. Retrieved from: https://www.caribank.org/newsroom/news-and-events/speeches/2019-annualnews-conference-dr-justin-ram (01.06.2020).

Smith, W. (2018). 2018 Annual News Conference. Statement. Caribbean Development Bank. Retrieved from: https://www.caribank.org/sites/default/files/publication-resources/CDB_ President_Statement_CDBAnnualNewsConference_Feb72018.pdf (01.06.2020).

The World Bank. (2020). Second enrollment, tertiary (\& gross), Retrieved from: https://data. worldbank.org/indicator/SE.TER.ENRR?locations=ZJ

Hilary Beckles is the 8th Vice-Chancellor of The University of the West Indies (The UWI), a distinguished academic, international thought leader, United Nations committee official and global public activist in the field of social justice and minority empowerment. Before assuming office as Vice-Chancellor in 2015, he served the university as Professor of Economic History, Pro-ViceChancellor for Undergraduate Studies, and Principal of the UWI Cave Hill Campus in Barbados for thirteen years (2002-2015).

Stacy Richards-Kennedy heads the regional Office of Global Partnerships and Sustainable Futures at The University of the West Indies (UWI). Dr. Richards-Kennedy has over 20 years' experience in development management and development financing. Previous appointments include Assistant Resident Representative of the United Nations Development Programme (UNDP) for Trinidad and Tobago, Aruba, Curaçao and Sint Maarten, Chief Technical Advisor, Inter-American Development Bank (IDB)-Washington DC, Consultant, The World Bank-Washington DC and Programme Specialist, UNESCO-Paris.

Open Access This chapter is licensed under the terms of the Creative Commons Attribution 4.0 International License (http://creativecommons.org/licenses/by/4.0/), which permits use, sharing, adaptation, distribution and reproduction in any medium or format, as long as you give appropriate credit to the original author(s) and the source, provide a link to the Creative Commons license and indicate if changes were made.

The images or other third party material in this chapter are included in the chapter's Creative Commons license, unless indicated otherwise in a credit line to the material. If material is not included in the chapter's Creative Commons license and your intended use is not permitted by statutory regulation or exceeds the permitted use, you will need to obtain permission directly from the copyright holder.

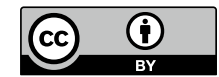

